\section{Graphical tool for assessing the critical temperatures of steel beams and columns in fire}

\author{
Valdir Pignatta Silva, \\ Arthur Ribeiro Melão, Igor Pierin \\ Polytechnic School, University of São \\ Paulo, Brazil
}

\begin{abstract}
In a fire situation, the temperature in which the ultimate limit state of the structural element is reached is called critical temperature. It is very laborious to determine it. The aim of this work was to create a graphical tool to allow quick determination of the critical temperature of I shaped columns and beams without local buckling. The method used was based on the Brazilian standard and using AcoInc software developed by the authors. The result was a tool whose similarity was not found in the literature. The use of the tool developed in this study simplifies the use of the standardized design method. One conclusion to be highlighted is one in which constants values of the critical temperature, generally accepted in practice, may be unsafe.
\end{abstract}

\section{Introduction}

Structural materials lose strength and modulus of elasticity with the increasing temperature in a fire. The Code of the Fire Department of the São Paulo State, ${ }^{1}$ base of almost all the others States of Brazil, requires that all buildings have their structure verified for fire situation. In this work, a new calculation tool is presented to simplify this verification.

In the case of elements of steel structures, beams and columns, subject to uniform temperature in their volume, there is a temperature that leads them to collapse. This is called critical temperature.

For simplicity and also to avoid possible damage to the test furnace, in several parts of the world a fixed value for critical temperature is used. For example: $550{ }^{\circ} \mathrm{C}$ based on LPS $1107,{ }^{2} 550{ }^{\circ} \mathrm{C}$ for columns and $620{ }^{\circ} \mathrm{C}$ for beams supporting concrete based on ASFP, ${ }^{3} 538^{\circ} \mathrm{C}$ for columns and $593^{\circ} \mathrm{C}$ for beams based on ASTM E119, ${ }^{4}$ $500{ }^{\circ} \mathrm{C}$ in several parts of Europe based on European Country Specific Fire Safety Standards and Guidance Documents apud Jowsey ${ }^{5}$ and $550{ }^{\circ} \mathrm{C}$ in Brazil. ${ }^{6}$

Despite the easiness of adopting an invariable value, this practice leads to unrealistic results. The critical temperature depends on the load, the span and the dimensions of the structural element. The critical temperature can be determined for each case of structural composition, although it is laborious.

The objective of this work is to present an expeditious tool to determine the critical temperature of columns and beams with an I - shaped cross section for three types of steel.

$\mathrm{ECCS}^{7}$ presents tables to determine the critical temperature just valid for columns, based on equations of outdated version of Eurocode 3, part 1-2 and limiting the relative slenderness index to 2.0.

Eurocode 3, part $1-2^{8}$ presents an equation to determine the critical temperature, but without taking into account stability phenomena. Silva ${ }^{6}$ presented graphics for critical temperature of columns using standards of that time. Silva ${ }^{9}$ adapted these graphics using updated standards. In the present paper a new updated was done and was included graphics for beams, considering lateral torsional buckling.

It is unusual to see tools like presented herein. For example in the most recent books on structures in fire that refer to steel structures, i.e., Garlock, ${ }^{10}$ Wang et al., ${ }^{11}$ Vila Real, ${ }^{12}$ Franssen et al., ${ }^{13}$ Parkinson, ${ }^{14}$ Franssen, ${ }^{15}$ Skowronsky, ${ }^{16}$ Vila Real ${ }^{17}$ and Wang ${ }^{18}$ nothing was found that look like the results presented herein.

\section{Materials and Methods}

We here considered that collapse is reached when the resistance is equal to the effect of the action, both in fire, i.e., when the structural element reached the Ultimate Limit State, as defined in standards.

Therefore, the critical temperature, for column or beam, can be determined by matching the design value of normal force $\left(\mathrm{N}_{\mathrm{fi}, \mathrm{Sd}}\right.$ for columns) and bending moment $\left(\mathrm{M}_{\mathrm{fi}, \mathrm{Sd}}\right.$ for beams) to their respective resistances $\left(\mathrm{N}_{\mathrm{fi}, \mathrm{Rd}}\right.$ and $\left.\mathrm{M}_{\mathrm{fi}, \mathrm{Rd}}\right)$ in fire. The Brazilian standards provide the procedures for determining the resistance at room temperature (ABNT NBR 8800:2008, ${ }^{19}$ based on AISC, 2005) $)^{20}$ and in fire (ABNT NBR 14323:2013, ${ }^{21}$ based on Eurocode 3, part 1$2 .{ }^{8}$ We here used the Brazilian standards. To determine critical temperature, a software was developed by the authors.

\section{Critical temperature in compression}

For doubly symmetric I profiles, without local buckling and at room temperature, Equation 1 is valid.
Correspondence: Valdir Pignatta Silva, Polytechnic School, University of São Paulo, Av. Prof. Luciano Gualberto, Trav. 3, n. 380.05508.010, São Paulo, Brazil.

Tel.: 55.11.30915562 - Fax: 55.11.30915181.

E-mail: valpigss@usp.br

Key words: Fire; Steel structure; Critical temperature; Column; Beam.

Contributions: VPS: conception, analysis and interpretation of data; writing, critical revision and final approval of the draft. Responsible for all aspects of the work as regards ensuring questions related to the accuracy of any part of the work. ARM: data acquisition and interpretation, writing; accountable for all aspects of the work as regards ensuring questions related to the accuracy or integrity of any part of the work. IP: data interpretation, graphs building.

Conflict of interest: the authors declare no potential conflict of interest.

Funding: the authors thank the São Paulo Research Foundation (FAPESP), the Coordination for the Improvement of Higher Education Personnel (CAPES) and the Brazilian National Council of Scientific and Technological Development (CNPq).

Conference presentation: part of this paper was presented at the 4th Ibero-Latin American Congress on Fire Safety ( $4^{\circ}$ CILASCI), 2017 Oct 9-11, Recife, Brazil.

Received for publication: 15 December 2017. Revision received: 31 May 2018.

Accepted for publication: 6 July 2018.

This work is licensed under a Creative Commons Attribution 4.0 License (by-nc 4.0)

CCopyright V. Pignatta Silva et al., 2018

Licensee PAGEPress, Italy

Fire Research 2018; 2:53

doi:10.4081/fire.2018.53

$\mathrm{N}_{\mathrm{Rd}}=\frac{\chi \mathrm{Af}_{\mathrm{y}}}{1,1}$

where $\chi$ is a reduction factor for the buckling curve determined according to Equation 2.

$$
\begin{aligned}
& \text { for } \lambda_{0} \leq 1,5 \rightarrow \chi=0,658^{\lambda_{0}^{2}} \\
& \text { for } \lambda_{0}>1,5 \rightarrow \chi=\frac{0,877}{\lambda_{0}^{2}}
\end{aligned}
$$

In Equation 2, $\lambda_{\mathrm{o}}$ is the relative slenderness that is determined by Equation 3 in general cases.

$\lambda_{0}=\sqrt{\frac{\mathrm{Af}_{\mathrm{y}}}{\mathrm{N}_{\mathrm{cr}}}}$ 
In Equation 3, $\mathrm{N}_{\mathrm{cr}}$ is the elastic critical force for the relevant buckling mode. However, considering only the case of flexural buckling, which happens in the double symmetrical profiles with I-shaped cross section, i.e., $\mathrm{N}_{\mathrm{cr}}=\left(\pi^{2} \mathrm{E} \mathrm{I}\right) / \mathrm{L}^{2}$, Equation 3 becomes Equation 4.

$$
\lambda_{0}=\frac{\lambda}{\sqrt{\frac{\pi^{2} E}{f_{y}}}}
$$

For doubly-symmetrical I profiles, without local instability in fire situation, Equation 5 is valid.

$\mathrm{N}_{\mathrm{fi}, \mathrm{Rd}}=\chi_{\mathrm{fi}} \mathrm{k}_{\mathrm{y}, \theta} \mathrm{Af}_{\mathrm{y}}$

where $\mathrm{k}_{\mathrm{y} \theta}$ is the reduction factor of the yield strength of steel in function of the temperature according to Table 1:

$\chi_{\mathrm{fi}}$ is the reducing factor of resistance to normal force according to Equation 6.

$$
\chi_{\mathrm{fi}}=\frac{1}{\varphi_{0, \mathrm{fi}}+\sqrt{\varphi_{0, \mathrm{fi}}^{2}-\lambda_{0, \mathrm{fi}}^{2}}}
$$

In Equation 6:

$\varphi_{0, \mathrm{fi}}=0,5\left(1+\alpha \lambda_{0, \mathrm{fi}}+\lambda_{0, \mathrm{fi}}^{2}\right)$

$\alpha=0,022 \sqrt{\frac{E}{f_{y}}}$

$\lambda_{\mathrm{o}, \mathrm{fi}}$ is the relative slenderness index in fire according to Equation 7

$\lambda_{\mathrm{ofi}}=\lambda_{0} \sqrt{\frac{\mathrm{k}_{\mathrm{y} \theta}}{\mathrm{k}_{\mathrm{E} \theta}}}$

In Equation 7, $\mathrm{k}_{\mathrm{E \theta}}$ is the reduction factor of the modulus of elasticity in function of the temperature, according to Table 1 .

From Equations 1 and 5, we derive Equation 8.

$$
\frac{\mathrm{N}_{\mathrm{fi}, \mathrm{Rd}}}{\mathrm{N}_{\mathrm{Rd}}}=1,1 \frac{\chi_{\mathrm{fi}} \mathrm{k}_{\mathrm{y}, \theta}}{\chi}
$$

At the moment of collapse, as defined in 2.1, $\mathrm{N}_{\mathrm{fi}, \mathrm{Rd}}=\mathrm{N}_{\mathrm{fi}, \mathrm{Ed}}$, where $\mathrm{N}_{\mathrm{fi}, \mathrm{Ed}}$ is the design value of the normal compressive force in a fire situation and the temperature is critical. Thus, we have Equation 9.

$\eta=\frac{\mathrm{N}_{\mathrm{fi}, \mathrm{Sd}}}{\mathrm{N}_{\mathrm{Rd}}}=1,1 \frac{\chi_{\mathrm{fi}} \mathrm{k}_{\mathrm{y}, \theta}}{\chi}$
Based on Equations 1, 2, 5, 6, 7 and Table 1, and knowing the type of steel, the value of the critical temperature can be determined. In view of the obvious difficulty in obtaining $\theta_{\mathrm{cr}}$ handily, the authors developed software that allowed building the curves presented in Figure 1. $\mathrm{N}_{\mathrm{Rd}}$ and $\lambda_{\mathrm{o}}$ are already known, resulting from the design at room temperature. Hence, using the proposed graphical method, the $\theta_{\text {cr }}$ of the column is calculated.

Three types of steels were chosen; their yield strengths are, respectively: $f_{y}=250$ $\mathrm{MPa}, \mathrm{f}_{\mathrm{y}}=300 \mathrm{MPa}$, and $\mathrm{f}_{\mathrm{y}}=350 \mathrm{MPa}$.

Those values are the $f_{y}$ for most used steel in Brazil: ASTM A 36 (ASTM, 2014), ${ }^{22} \mathrm{f}_{\mathrm{y}}=250$ MPA, USI-Civil 300 (USIMINAS, 2018), ${ }^{23} \mathrm{f}_{\mathrm{y}}=300 \mathrm{MPA}$, and USI-Civil 350 (USIMINAS, 2018), ${ }^{23} \mathrm{f}_{\mathrm{y}}=$ 350 MPA.

\section{Critical temperature in bending}

Differently from the normal compression force, the bending moment resistance at room temperature is not presented by the Brazilian standard by means of a curve $\chi \mathrm{x}$ $\lambda_{\mathrm{o}}$ but $\mathrm{M}_{\mathrm{Rk}} \times \lambda_{\mathrm{b}}$ according to Equation 10, in which, by simplification, $\mathrm{C}_{\mathrm{b}}$ was considered unitary, with $\mathrm{C}_{\mathrm{b}}$ being the modification factor for a non-uniform bending moment diagram, according to the Brazilian standard.

$$
\begin{aligned}
& M_{R k}=M_{p l} \text {, for } \lambda_{b} \leq \lambda_{p} \\
& M_{R k}=\left[M_{p l}-\left(M_{p l}-M_{r}\right) \frac{\lambda-\lambda_{p}}{\lambda_{r}-\lambda_{p}}\right], \text { for } \lambda_{p}<\lambda_{b} \leq \lambda_{r} \\
& M_{R k}=M_{c r} \leq M_{p l} \text { for } \lambda_{b}>\lambda_{r}
\end{aligned}
$$

In Equation 10:

$\mathrm{M}_{\mathrm{pl}}=\mathrm{W}_{\mathrm{pl}, \mathrm{x}} \mathrm{f}_{\mathrm{y}}$

$\mathrm{M}_{\mathrm{r}}=0,7 \mathrm{f}_{\mathrm{y}} \mathrm{W}_{\mathrm{pl}, \mathrm{x}}$

$$
\lambda_{p}=1,76 \sqrt{\frac{E}{f_{y}}}
$$

The authors made a change in the variables to reach the dimensionless relation $\chi_{\mathrm{FLT}} \times \lambda_{\mathrm{o}, \mathrm{FLT}}$, according to Equations 11 and 12.

$$
\begin{aligned}
& \chi_{\mathrm{FLT}}=\frac{\mathrm{M}_{\mathrm{Rk}}}{\mathrm{M}_{\mathrm{pl}}} \\
& \chi_{\mathrm{FLT}}=\frac{\mathrm{m}_{\mathrm{Rk}}}{\mathrm{M}_{\mathrm{pl}}}
\end{aligned}
$$

Using Equations 10 to 12 , we have Equation 13.

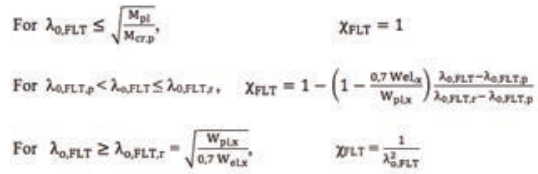

(13)

In Equation 13:

$\lambda_{0, \mathrm{FLT}, \mathrm{p}}=\sqrt{\frac{\mathrm{M}_{\mathrm{pl}}}{\mathrm{M}_{\mathrm{cr}, \mathrm{p}}}}$

$\lambda_{0, \mathrm{FLT}, \mathrm{r}}=\sqrt{\frac{\mathrm{M}_{\mathrm{pl}}}{\mathrm{M}_{\mathrm{r}}}}=\sqrt{\frac{\mathrm{W}_{\mathrm{pl}, \mathrm{x}}}{0,7 \mathrm{~W}_{\mathrm{el}, \mathrm{x}}}}$

$\mathrm{M}_{\mathrm{e}, \mathrm{p}}$ is the critical moment to elastic buckling in $\lambda=\lambda_{\mathrm{p}}$ (hence out of grapph $\chi_{\mathrm{FLT}}$ $\mathrm{x} \lambda_{\mathrm{o}, \mathrm{FLT}}$ ).

For I doubly-symmetrical profiles without local buckling, according to the Brazilian standard, Equation 14 is valid for fire situations.

$\mathrm{M}_{\mathrm{fi}, \mathrm{Rd}}=\kappa \chi_{\mathrm{FLT}, \mathrm{fi}} \mathrm{W}_{\mathrm{pl}, \mathrm{x}} \mathrm{f}_{\mathrm{y}} \mathrm{k}_{\mathrm{y}, \theta}$

In Equation 14:

$\chi_{\mathrm{FLT}, \mathrm{fi}}$ is similar $\chi_{\mathrm{fi}}$ (Equation 6) but changing $\lambda_{\mathrm{o}, \mathrm{f}} \mathrm{i}$ (Equation 7 ) according to Equation 15 .

$\lambda_{\mathrm{o}, \mathrm{FLT}, \mathrm{fi}}=\sqrt{\frac{\mathrm{k}_{\mathrm{y}, \theta}}{\mathrm{k}_{\mathrm{E}, \theta}}} \sqrt{\frac{\mathrm{M}_{\mathrm{pl}}}{\mathrm{M}_{\mathrm{cr}}}}$

As was done for normal force, a dimensionless relation $\mathrm{m}$, will be created, according to Equation 16.

$\mu=\frac{M_{\mathrm{fi}, \mathrm{Rd}}}{\mathrm{M}_{\mathrm{Rd}}}=1,1 \frac{\kappa \mathrm{k}_{\mathrm{y}, \theta} \chi_{\mathrm{FLT}, \mathrm{fi}}}{\chi_{\mathrm{FLT}}}$

Based on Equations 13, 14, 15, 16 and on Table 1, and knowing the type of steel, it is possible to determine the value of the critical temperature. Due to the obvious diffi-

Table 1. Reduction factor.

\begin{tabular}{lcc}
$\theta_{\mathrm{a}}\left({ }^{\circ} \mathrm{C}\right)$ & $\mathrm{k}_{\mathrm{y}, \theta=\mathrm{f}_{\mathrm{y} \theta} / \mathrm{f}_{\mathrm{y}}}$ & $\mathrm{k}_{\mathrm{E} y \theta}=\mathrm{E}_{\theta \theta} / \mathrm{E}$ \\
20 & 1.000 & 1.000 \\
100 & 1.000 & 1.000 \\
\hline 200 & 1.000 & 0.900 \\
300 & 1.000 & 0.800 \\
\hline 400 & 1.000 & 0.700 \\
500 & 0.780 & 0.600 \\
\hline 600 & 0.470 & 0.310 \\
700 & 0.230 & 0.130 \\
\hline 800 & 0.110 & 0.090 \\
900 & 0.060 & 0.0675 \\
\hline 1000 & 0.040 & 0.0450 \\
1100 & 0.020 & 0.0225 \\
\hline 1200 & 0.000 & 0.000 \\
\hline
\end{tabular}


culty in obtaining $\theta_{\text {cr }}$ handily, the authors developed software that allowed building the curves presented in Figures 2-4. $\mathrm{M}_{\mathrm{Rd}}$ and $\lambda_{\mathrm{o}}$ are already known, resulting from the design at room temperature. The materials are the same as those used for the columns. Hence, using the proposed graphical method, the $\theta_{\text {cr }}$ of the beam is calculated.

For the series of Brazilian hot profiles, the value of $\sqrt{\frac{\mathrm{M}_{\mathrm{pl}}}{\mathrm{M}_{\mathrm{cr}, \mathrm{p}}}}$ was determined,

deriving Table 2 .

Therefore, $\mu$ is known by Equation 16 . $\lambda_{\mathrm{o}, \mathrm{FLT}}$ is determined by Equation 12 . Hence, by the proposed graphical method, the $\theta_{\text {cr }}$ of the beam is calculated.

For the graphs, we used $\kappa=1$, but for other values of $\kappa$, they can also be used with the following strategy: from $\theta_{\mathrm{cr}}$ determined with the graphs, we find the value of $\mathrm{k}_{\mathrm{y}, \mathrm{q}=\mathrm{qcr}}$, then the new $\mathrm{q}_{\mathrm{cr}}$ is calculated from approximately $\mathrm{k}_{\mathrm{y}, \mathrm{q}}=\mathrm{k}_{\mathrm{y}, \theta=\theta \mathrm{cr}} / \kappa$.

\section{Software}

The authors developed a piece of software. Macro features were used, employing Visual Basic for Applications programming language associated with the Excel software, making spreadsheets more agile.

The software builds graphs that allow, from some data, the expeditious graphical determination of the critical temperature based on Brazilian standards.

For input data, structural element (beam or column), type of steel $\left(\mathrm{f}_{\mathrm{yk}}\right)$, relation between plastic $\left(\mathrm{W}_{\mathrm{pl}}\right)$ and elastic $\left(\mathrm{W}_{\mathrm{el}}\right)$ modulus for beams, $\eta$ (for columns) or $m$ (for beams), i.e., the relationship between effect of the design actions in fire and the resistance at room temperature as in Equations 17 and 18 and the relative slenderness index $\left(\lambda_{0}\right)$ at room temperature, the software builds the curve that will allow determining the critical temperature

$\mu=\frac{\mathrm{M}_{\mathrm{fi}, \mathrm{Sd}}}{\mathrm{M}_{\mathrm{Rd}}}$

Table 2. Values of $\sqrt{\frac{M_{p l}}{M_{c r, p}}}$.

\begin{tabular}{lcc}
\hline fy (MPa) & $\sqrt{\frac{\mathbf{M}_{\mathbf{p l}}}{\mathbf{M}_{\mathbf{c r}, \mathbf{p}}}}$ \\
\hline & Variation & \\
\hline 250 & Between 0.48 and 0.55 & 0.48 \\
300 & Between 0.52 and 0.60 & 0.52 \\
\hline 345 & Between 0.56 and 0.65 & 0.56 \\
350 & Between 0.56 and 0.65 & 0.56 \\
\hline
\end{tabular}

$$
\eta=\frac{N_{f i, S d}}{N_{R d}}
$$

Care has been taken to facilitate using the curves. The effect of actions in fire is easy to calculate and the resistance as well as the relative slenderness should already be included in the calculation report of the structure at room temperature. The equation that allows determining the relative slenderness index $\lambda_{o}$ for columns at room temperature is provided according to Equation 4.

For each profile, the software calculates the values of $\mathrm{N}_{\mathrm{Rd}}, \mathrm{M}_{\mathrm{Rd}}, \mathrm{N}_{\mathrm{fi}, \mathrm{Rd}}$ and $\mathrm{M}_{\mathrm{fi}, \mathrm{Rd}}$. $\mathrm{By}$ adopting a load level $\mu$ or $\eta$ and depending on the relative slenderness index, it is possible to find a temperature to match $\mathrm{N}_{\mathrm{fi}, \mathrm{Ed}}$ to $\mathrm{N}_{\mathrm{fi}, \mathrm{Rd}}$ (for columns) or $\mathrm{M}_{\mathrm{fi}, \mathrm{Ed}}$ to $\mathrm{M}_{\mathrm{fi}, \mathrm{Rd}}$ (for beams).

\section{Results and Discussion}

The critical temperature can be obtained by means of the graphs of Figures 1-4. In the construction of the graphs of Figures 24 , by simplification and for safety, $\mathrm{C}_{\mathrm{b}}$ was considered to be 1 .

A constant value of the critical temperature, widely used in practice (see introduction of this paper), can be very different, depending on the structural situation.

Note that the graphs presented are valid for profiles that do not present local instability of the web and flange. In addition, relative slenderness in fire is increased by about $15 \%$, which causes profiles with local slenderness values close to the limit at room temperature to be subject to local instability in a fire situation. In cases of local instability occurring at both ambient and fire temperatures, the curves shown may be used for pre-design.

Care should be taken in analysing these curves, since it seems paradoxical that all curves have a minimum point for values of slenderness between 1.0 and 1.5 , which can lead to the false impression that the critical temperature increases if its relative slenderness index increases. This is explained when changing the value of $\lambda_{0}$ or $\lambda_{0, \mathrm{FLT}}$, the buckling length is also changed and, consequently, the values of $N_{R d}$ and $\eta$ for columns and $\mathrm{M}_{\mathrm{Rd}}$ and $\mu$, for beams. That is, to analyse the behaviour of the bar, another curve must be used and this will lead to results consistent with the expected.

The bottoms of some lines are interrupted when reaching $100{ }^{\circ} \mathrm{C}$. At this temperature, the values of $\mathrm{k}_{\mathrm{y}, \theta}$ e $\mathrm{k}_{\mathrm{E}, \theta}$ become unitary, i.e., there is no reduction of the properties of the steel.

In Figures 2 and 3, graphs were presented for beams without lateral bracing.

In the case of non-composite beams continuously laterally braced by slabs, the solution is simplified by the absence of lateral torsional buckling, and the graph shown in Figure 4 is valid for any beam I without local and lateral buckling.

To build Figure 4, we also considered that the average temperature is reduced due

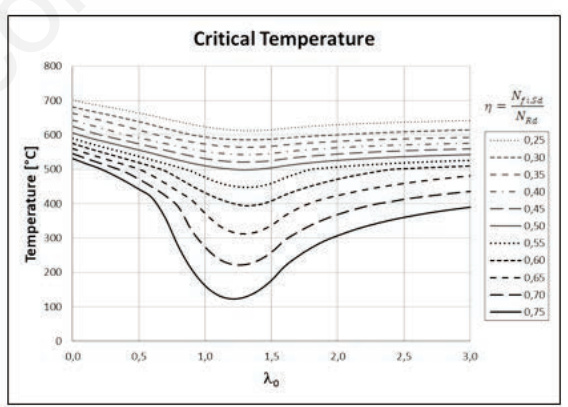

A

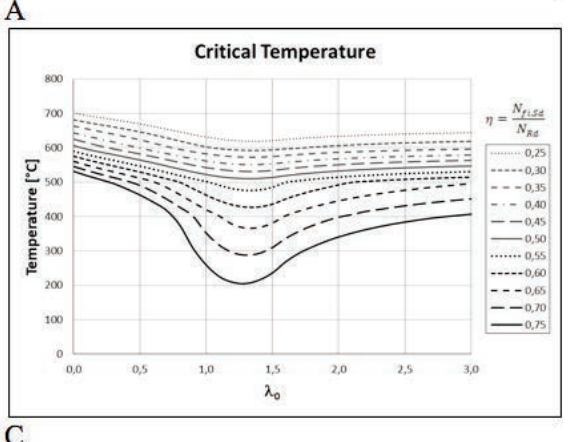

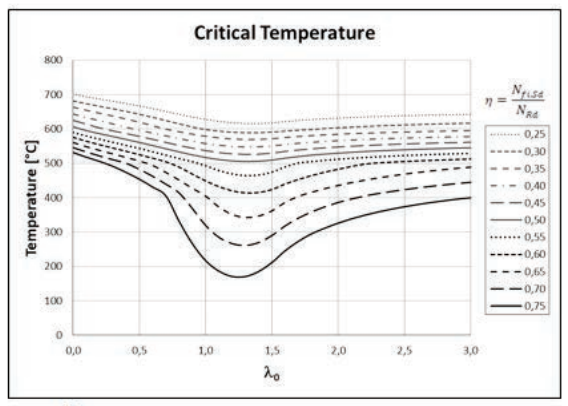

B

Figure 1. Critical temperature of columns in function of the relative slenderness index and level of load for A) $f_{y}=250 \mathrm{MPa}$; ) $f_{y}=300 \mathrm{MPa}$; C) $f_{y}=350 \mathrm{MPa}$. 
to the presence of the slab, according to the procedure recommended by ABNT NBR 14323: 2013, i.e., the design value of resistance to bending moment considering the thermal gradient along the height of the

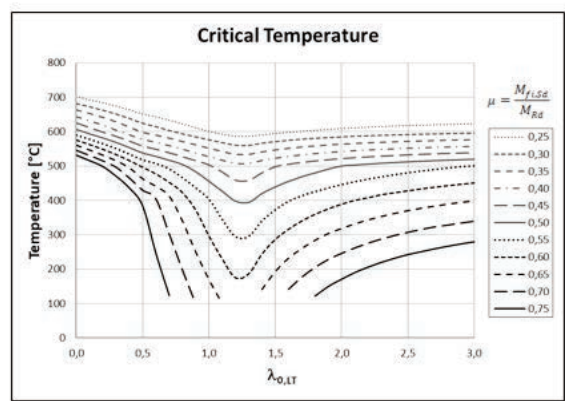

A

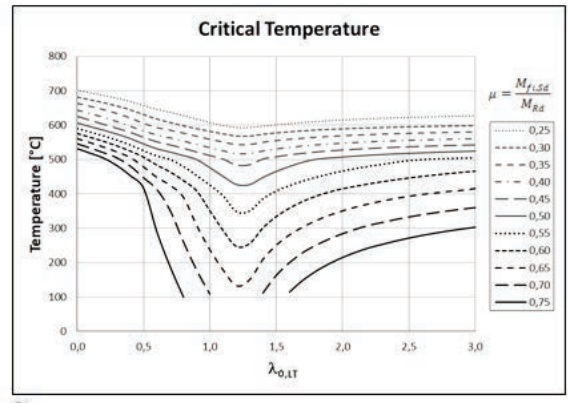

$\mathrm{C}$

Figure 2. Critical temperature of beams in function of the relative slenderness index and level of load for $\frac{w_{p l, x}}{W e l, x}=1.10$ and A) $f_{y}=250 \mathrm{MPa}$; $) f_{y}=300 \mathrm{MPa}$ C) $f y=350 \mathrm{MPa}$.

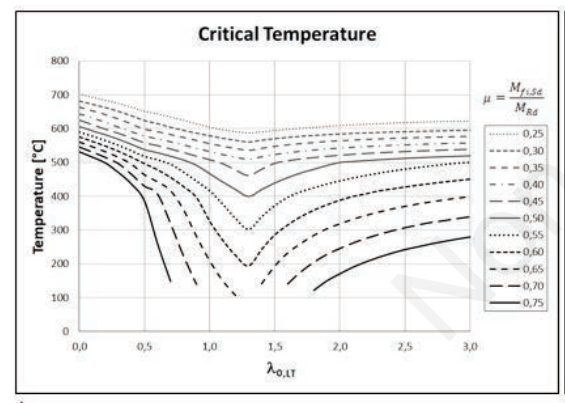

A

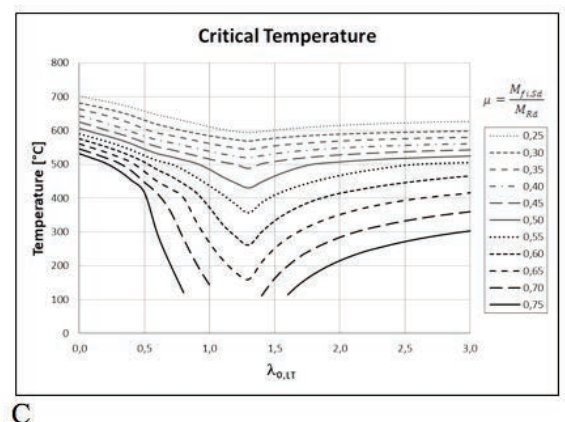

Figure 3. Critical temperature of beams in function of the relative slenderness index and level of load for $\frac{W p l, x}{W e l, x}=1.20$ and A) $f_{y}=250 \mathrm{MPa}$; ) $f_{y}=300 \mathrm{MPa}$ C) $f y=350 \mathrm{MPa}$. beam is 1.4 times the design value of the resistance to bending moment at uniform temperature.

In Figure 4, neither local buckling of flange or web were taken into account.

B

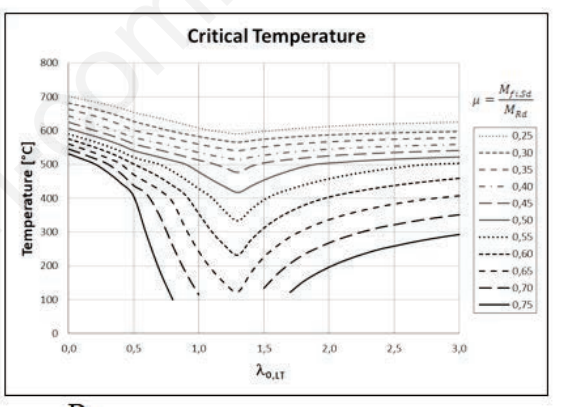

B

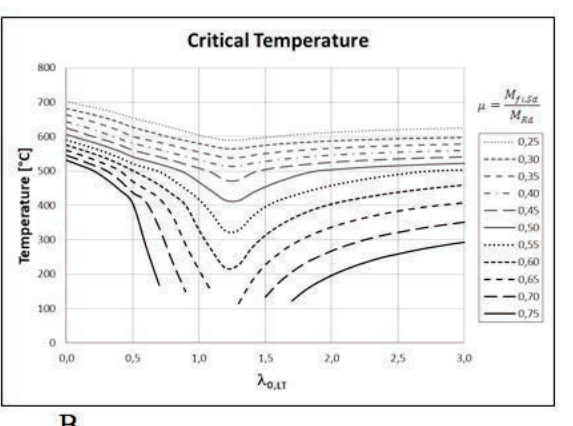

It is important to highlight that the critical temperature based on the graphs may be less economical as compared to the results of analyses of structural subsets (for example: composite beams under composite slabs or columns close walls) that lead to non-uniform thermal fields. However, they would require complex computational or experimental analysis. Nevertheless, the critical temperatures found through the graphs can serve as pre-design.

\section{Examples}

To clarify the use of graphics, here are some examples.

Example 1 - Determine the critical temperature of the beam with the following characteristics:

$\mathrm{f}_{\mathrm{y}}=250 \mathrm{MPa}$

simply supported beam without slab above it

$\mathrm{L}=600 \mathrm{~mm}$

It is used a welded profile with: $\mathrm{h}=400$ $\mathrm{mm} ; \mathrm{b}_{\mathrm{f}}=140 \mathrm{~mm} ; \mathrm{t}_{\mathrm{f}}=8 \mathrm{~mm} ; \mathrm{t}_{\mathrm{w}}=4.75 \mathrm{~mm}$ $\mathrm{M}_{\mathrm{Rd}}=45.49 \mathrm{kN} \mathrm{m}$

$\mathrm{M}_{\mathrm{Sd}}($ assumed $)=0.945 .49=40.9$

$\mathrm{W}_{\mathrm{pl}, \mathrm{x}} / \mathrm{W}_{\mathrm{el}, \mathrm{x}}=614 / 542=1.13$

$\mathrm{M}_{\mathrm{Sd}, \mathrm{fi}}($ assumed $)=0.6 \times 40.9=24.6 \mathrm{kN} \mathrm{cm}$ $\mu=\mathrm{M}_{\mathrm{Sd}, \mathrm{fi}} / \mathrm{M}_{\mathrm{Rd}}=0.54$

$\mathrm{M}_{\mathrm{pl}}=153.5 \mathrm{kN} \mathrm{m}$

$\mathrm{M}_{\mathrm{cr}}=50.04 \mathrm{kN} \mathrm{m}$

$$
\lambda_{0, \mathrm{FLT}}=\sqrt{\frac{\mathrm{M}_{\mathrm{pl}}}{\mathrm{M}_{\mathrm{cr}}}}=(153.5 / 50.04)^{0.5}=1.75
$$

Using Figures $2 \mathrm{~A}$ and $3 \mathrm{~A}$, the critical temperature is $430{ }^{\circ} \mathrm{C}$

Example 2 - Determine the critical temperature of the same beam of example 1, with a slab on it but no composite beam.

Based on Figure 4, the critical temperature is about $6500^{\circ} \mathrm{C}$.

Example 3 - Determine the critical temperature of the column with the following characteristics:

$\mathrm{f}_{\mathrm{y}}=350 \mathrm{MPa}$

simply supported column

$\mathrm{L}=3000 \mathrm{~mm}$

It is used a hot rolled profile with: $\mathrm{h}=246$ $\mathrm{mm} ; \mathrm{b}_{\mathrm{f}}=256 \mathrm{~mm} ; \mathrm{t}_{\mathrm{f}}=10.7 \mathrm{~mm} ; \mathrm{t}_{\mathrm{w}}=10.5$ $\mathrm{mm}$

$\mathrm{A}=79.6 \mathrm{~cm}^{2}$

$\mathrm{N}_{\mathrm{Rd}}=2120.8 \mathrm{kN}$

$\mathrm{N}_{\mathrm{Sd}}$ (assumed) $=0.92120 .8=1908,7$

$\mathrm{N}_{\mathrm{Sd}, \text { fi }}$ (assumed) $=0.6 \times 1908,7=1145.2 \mathrm{kN}$

$\mathrm{h}=\mathrm{N}_{\mathrm{Sd}, \mathrm{fi}} / \mathrm{N}_{\mathrm{Rd}}=0.54$

$\mathrm{N}_{\mathrm{cr}}=6569 \mathrm{kN}$

$$
\lambda_{0}=\sqrt{\frac{\mathrm{Af}_{\mathrm{y}}}{\mathrm{N}_{\mathrm{cr}}}}=0.65
$$

Using Figure 1C, the critical temperature is $505.6^{\circ} \mathrm{C}$. 


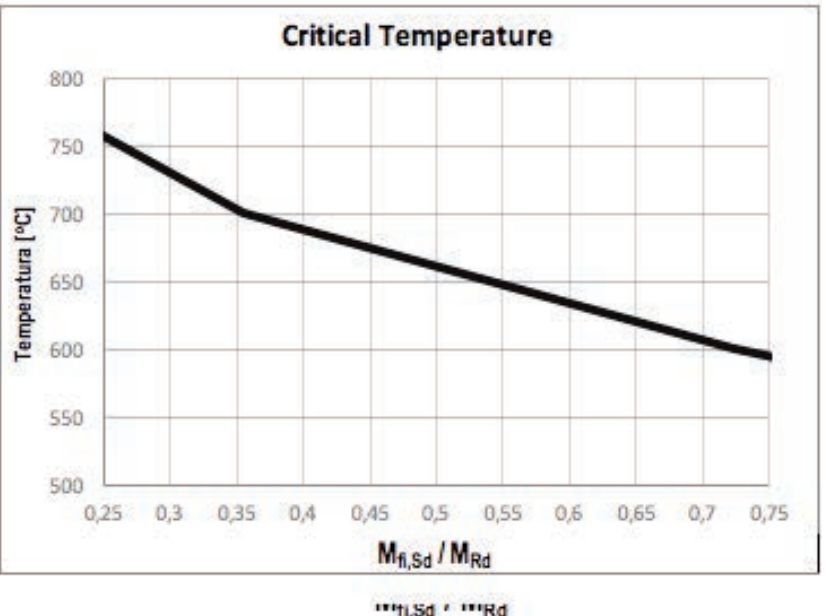

$m+1, S d$ ' mRd

Figure 4. Critical temperature of non-composite beams under slab in function of level of load.

\section{Conclusions}

A piece of software was developed to determine the critical temperature of beams and columns and graphs for profiles not subject to local buckling, in function of the relative slenderness index at room temperature; also, the level of loading of the element in a fire was built. These graphs were built based on Brazilian Standards. Their part of fire steel design is based on Eurocode 3 part 1-2 (2005). ${ }^{8}$ The tool here presented was not found in the researched literature. Constant values of the critical temperature, widely used in practice, can be very different, depending on the structural situation. At that time, it was necessary to create constant values, due to the lack of design standards and the difficulty of determining the critical temperature. With the current standards, it is possible to find the critical temperatures according to the structural system. The tool presented here will help in this determination.

The fire design, in which the critical temperature is compared to the steel temperature, base of the standardized methods, is greatly simplified if the graphs presented here are used.

The value of critical temperature based on the graphs may be less economical as compared to the results of analyses of structural subsets that lead to non-uniform thermal fields. However, they would require complex computational or experimental analysis. Nevertheless, the critical temperatures found through the graphs can serve as pre-design.

For future works, maintaining the objective of creating simple tools for using in design practice, the intention is to study more complex structures and to include the effects of local buckling.

\section{Nomenclature}

A area

E modulus of elasticity

$f_{y}$ characteristic value of the yield strength at normal temperature

$\mathrm{k}_{\mathrm{E}, \mathrm{q}}$ reduction factor of the modulus of elasticity of steel in function of the temperature

$\mathrm{k}_{\mathrm{y} \theta}$ reduction factor of the yield strength of steel in function of the temperature

$1_{b} \quad$ distance between lateral bracings

$M_{c r}$ critical moment to elastic buckling

$\mathrm{M}_{\mathrm{cr}, \mathrm{p}}$ critical moment to elastic buckling in $\lambda$ $=\lambda_{\mathrm{p}}$

$\mathrm{M}_{\mathrm{fi}, \mathrm{Sd}}$ design value of the effect of bending moment, in fire

$\mathrm{M}_{\mathrm{fi} \text { Rd }}$ characteristic value of resistance to bending moment, in fire

$\mathrm{M}_{\mathrm{pl}}$ characteristic value of plastification moment

$M_{r}$ limit moment between elastic and inelastic regime

$\mathrm{M}_{\mathrm{Rd}}$ design value of resistance to bending moment at room temperature

$\mathrm{M}_{\mathrm{Rk}}$ characteristic value of the resistance to bending moment

$\mathrm{N}_{\mathrm{cr}}$ critical force for the elastic buckling

$\mathrm{N}_{\mathrm{fi}, \mathrm{Sd}}$ design value of the effect of normal force, in fire

$\mathrm{N}_{\mathrm{fi}, \mathrm{Rd}}$ design value of resistance to normal force, in fire

$\mathrm{N}_{\mathrm{Rd}}$ design value of resistance to normal force

$\mathrm{W}_{\mathrm{el}, \mathrm{x}}$ elastic section modulus

$\mathrm{W}_{\mathrm{pl}, \mathrm{x}}$ plastic section modulus

1 slenderness

$1_{b} \quad$ slenderness associated to $l_{b}$

$\lambda_{\mathrm{o}, \mathrm{fi}}$ relative slenderness index in fire

$\lambda_{\mathrm{o}, \mathrm{FLT}}$ relative slenderness index associated to lateral buckling

$1_{\mathrm{o}, \mathrm{FLT}, \mathrm{fi}}$ relative slenderness index associated to lateral buckling in fire

$\lambda_{\mathrm{p}}$ slenderness at the end of the plastic regime

$\lambda_{\mathrm{r}} \quad$ limit slenderness between linear elastic and inelastic regimes

$\kappa$ correction factor taking into account non-uniform temperature distribution along the cross-sectional, between 1.0 and 1.4

c reducing factor of resistance to normal force

$\mathrm{c}_{\mathrm{fi}}$ reducing factor of resistance in fire to normal force

$\chi_{\mathrm{FLT}}$ reducing factor of resistance to bending moment

$\chi_{\text {FLT,fi }}$ reducing factor of resistance in fire to bending moment

$\theta$ temperature

$\theta_{\text {cr }} \quad$ critical temperature

\section{References}

1. Fire Department of São Paulo State. Code of Fire Safety. São Paulo, BR; 2018.

2. LPS. Loss prevention standard requirements. Tests and methods of assessment of passive fire protection systems for structural steelwork. LPS 1107. BRE. U.K; 2014.

3. Association of Specialist Fire Protection Engineers (ASFP). Fire Protection for Structural Steel in Buildings. 4th ed; 2010. Available from: http://asfp.associationhouse.org.uk/defa ult.php? cmd $=213$

4. ASTM E119. Standard test methods for fire tests of building construction and materials. Pennsylvania; 2010. Available from: https://www.astm.org/ DATABASE.CART/STD REFERENCE/E119.htm

5. Jowsey A, Scott P. An overview of optimising passive fire protection using a limiting temperature by structural assessment. J Struct Fire Engin 2014;5.

6. Silva VP. Estruturas de aço em situação de incêndio. [Steel structures in fire]. Sao Paulo, BR: Zigurate; 2004.

7. European Community for Coal and Steel (ECCS). Fire resistance of steel structures. ECCS n. 89. Brussels; 1995.

8. European Committee for Standardization. Design of steel structures (1-2). General rules - Structural fire design. Brussels: Eurocode 3; 2005.

9. Silva VP, Velarde JS. Sobre o dimensionamento de pilares de aço em situação de incêndio. Revisão da NBR 14323. (On Steel Fire Design. Contribution to Brazilian Standard). Rev Sul-Am Engen Estrut 2010;6:44-64.

10. Garlock M, Kodur V. Structures in Fire 2016: Proceedings of the Ninth International Conference (SiF16), June 8-10, 2016. Princeton University, 
Princeton, USA.

11. Wang Y, Burgess I, Wald F, Gillie M. Performance-based fire engineering of structures. USA: Span Press; 2013.

12. Vila Real P, Franssen JM. Fire design of steel structures. European Convention for Constructional Steelwork. New York: Wiley; 2010.

13. Franssen JM, Zaharia R, Kodur V. Designing steel structures for fire safety. USA: CRC Press; 2009.

14. Parkinson D, Kodur V. Performancebased of structural steel for fire conditions. Am Soc Civil Eng 2008;124.

15. Franssen JM, Zaharia R. Design of steel structures subject to Fire. Liège: Université de Liège; 2005.

16. Skowronski W. Fire safety of metal structures. Theory and design criteria. Warsaw: Polish Scientific Publishers; 2004.

17. Vila Real P. Incêndio em Estruturas Metálicas. Cálculo Estrutural. Lisbon: Orion; 2003.

18. Wang YC. Steel and composite structures behaviour and design for fire safety. New York: Spon Press; 2002.

19. Associação Brasileira de Normas Técnicas. NBR 8800: Projeto de estruturas de aço e de estruturas mistas de aço e concreto de edifícios. Rio de Janeiro, BR; 2008.

20. American Institute of Steel Construction, Inc. AISC 360-05. Specification for Structural Steel Buildings. Chicago, IL: AISC; 2005.
21. Associação Brasileira de Normas Técnicas. NBR 14323: Dimensionamento de estruturas de aço de edifícios em situação de incêndio. Rio de Janeiro, BR; 2013.

22. ASTM A36. Standard Specification for Carbon Structural Steel, ASTM International. Pennsylvania; 2014. Available from: https:/www.astm. org/DATABASE.CART/STD_REFERENCE/E119.htm

23. USIMINAS Catalog. Available from http://www.usiminas.com/solucoes/wpcontent/uploads/sites/5/2013/12/su-catalogo-online.pdf. Accessed 13 May 2018. 